\title{
A fatal case of descending necrotizing mediastinitis as a complication of odontogenic infection. A case report
}

\author{
Bogumił Lewandowski ${ }^{1,2}$, Paweł Pakla², Wojciech Wołek ${ }^{3}$, Mariusz Jednakiewicz ${ }^{4}$, Jakub Nicpoń ${ }^{4}$ \\ ${ }^{1}$ Department of Emergency Medicine, University of Rzeszów, Poland \\ ${ }^{2}$ Clinical Department of Maxillofacial Surgery, Regional Specialist Hospital, Rzeszów, Poland \\ ${ }^{3}$ Department of Thoracic Surgery, Subcarpathian Lung Diseases Centre in Rzeszów, Poland \\ ${ }^{4}$ Department of Anesthesiology and Intensive Care, Regional Specialist Hospital, Rzeszów, Poland
}

Kardiochirurgia i Torakochirurgia Polska 2014; 11 (3): 324-328

\begin{abstract}
This paper presents the case of a 26-year-old female patient in whom descending necrotizing mediastinitis (DNM) developed as a complication of an odontogenic purulent infection of the mouth. Despite the efforts of a multidisciplinary treatment team, the patient died with symptoms of septic shock and multiple organ failure. According to the literature, and as confirmed by our own observations, successful treatment requires early tomographic diagnosis, radical surgery, combination antibiotic therapy, and intensive care.

Key words: phlegmon of the face, descending mediastinitis, complications.
\end{abstract}

\section{Introduction}

Purulent conditions of the mediastinum and lungs spread by continuity through the interfascial spaces of the neck are among the rarest complications of odontogenic inflammatory processes of the oral cavity. Descending necrotizing mediastinitis (DNM) is a noteworthy example of such infection, originating from inflammatory conditions within the oral cavity and teeth [1].

Descending necrotizing mediastinitis develops in patients between 30 and 50 years old and occurs six times more frequently among men. The symptoms characteristic of DNM include strong retrosternal pain (intensifying during breathing and coughing), rapid breathing, tachycardia, increased body temperature, and inflammatory infiltration of the neck and chest. Treatment consists in combining broad-spectrum antibiotic therapy with radical dissection and drainage of the purulent foci located in the chest and mediastinum. Despite intensive treatment, DNM mortality remains high, amounting to as much as $20-50 \%$ of cases.

\section{Streszczenie}

W pracy przedstawiono przypadek 26-letniej chorej, u której w następstwie powikłań zębopochodnej infekcji ropnej jamy ustnej doszło do zstępującego martwiczego zapalenia śródpiersia (ZMZŚ). Pomimo wielospecjalistycznego zespołowego leczenia pacjentka zmarła z objawami wstrząsu septycznego i niewydolności wielonarządowej. Według piśmiennictwa specjalistycznego, co potwierdzają również obserwacje własne, kluczem do sukcesu leczenia jest wczesna diagnostyka tomograficzna, radykalne leczenie chirurgiczne, szerokospektralna, skojarzona antybiotykoterapia i intensywna opieka medyczna. Słowa kluczowe: ropowica twarzy, zstępujące zapalenie śródpiersia, powikłania.

\section{Aim of the study}

The aim of this study was to present the case of a 26-year-old woman treated at the Clinical Department of Maxillofacial Surgery and the Department of Anesthesiology and Intensive Care of the Regional Specialist Hospital in Rzeszów, in whom, in consequence of odontogenic infection and phlegmon of the face and neck, DNM developed with numerous lung and mediastinal abscesses, resulting in the patient's death. Descending necrotizing mediastinitis as a complication of odontogenic infections is rarely encountered in everyday practice; therefore, it appears purposeful to report the case of this patient who was recently treated at our department.

\section{Case study}

The 26-year-old female patient was admitted to the Clinical Department of Maxillofacial Surgery of the Regional Specialist Hospital in Rzeszów due to a swelling of the left cheek (which spread to the mental region before invoIving bilaterally the submandibular region), difficulties with

Address for correspondence: Paweł Pakla, Clinical Department of Maxillofacial Surgery, Regional Specialist Hospital, Chopina 2, 
swallowing, and limited jaw opening. Several days before the appearance of the swelling, the patient had experienced tooth pain on the left side of the mandible, which she found difficult to locate precisely. A clinical examination was performed, revealing a massive swelling of the left cheek and the submandibular and mental regions. The skin in this area was tense, reddened, and warm. Neck lymph nodes on both sides were unavailable for examination due to the swelling as well as significant local pain. Difficulties with jaw opening (approximately $20 \mathrm{~mm}$ ) were confirmed. Intraoral examination revealed insufficient oral hygiene, numerous tooth roots and teeth with their pulp in a state of gangrenous decay, and pain on percussion of teeth 36 and 46. The mucous membrane of the floor of the oral cavity had undergone inflammatory changes, and a hard, painful infiltrate was present. Tongue mobility was slightly limited on the left side. The hard and soft palate and the palatine arches and tonsils were not swollen. The ductal openings of the salivary glands were patent. At admittance, the patient's life parameters were within normal ranges: body temperature $31.1^{\circ} \mathrm{C}$, heart rate $80 \mathrm{bpm}$, arterial pressure 140/80 $\mathrm{mmHg}$. Laboratory investigation revealed high leukocytosis $\left(43100 / \mathrm{mm}^{3}\right)$, electrolyte impairments - reduced levels of sodium and chlorides $\left(\mathrm{Na}^{+} 130 \mathrm{mmol} / \mathrm{l}\right.$ and $\mathrm{Cl}^{-} 95.0$ $\mathrm{mmol} / \mathrm{l})$, glucose concentration increased to approximately $180 \mathrm{mg} / \mathrm{dl}$, and CRP $44.3 \mathrm{mg} / \mathrm{dl}$. The remaining parameters, i.e. morphology, coagulation parameters, biochemical tests, urea, and creatinine, were within the normal ranges.

Ultrasound examination of the neck revealed a hypoechogenic area of irregular shape located in the mental region at the depth of 1.5 to $4 \mathrm{~cm}$ - probably an inflammatory infiltrate. The soft tissues neighboring the area on both sides were swollen. The contour of the right submandibular gland was irregular and obscured. Lymph nodes around the salivary gland and the right corner of the mandible were of irregular shape, hypoechogenic, and swollen to $22 \times 13 \mathrm{~mm}$. Panoramic radiography revealed extensive damage to the hard tissue of teeth 18,46 , and 47 , reaching the pulp chambers of the teeth; presence of tooth roots 14, 26, and 34; and thinned bone structure characteristic of chronic periapical periodontitis in the vicinity of the apexes of teeth 34, 46, and 47 (Fig. 1).

The patient underwent pharmacological treatment, receiving antibiotics (clindamycin), analgesics, and steroids (dexamethasone); subsequently, under general anesthesia,

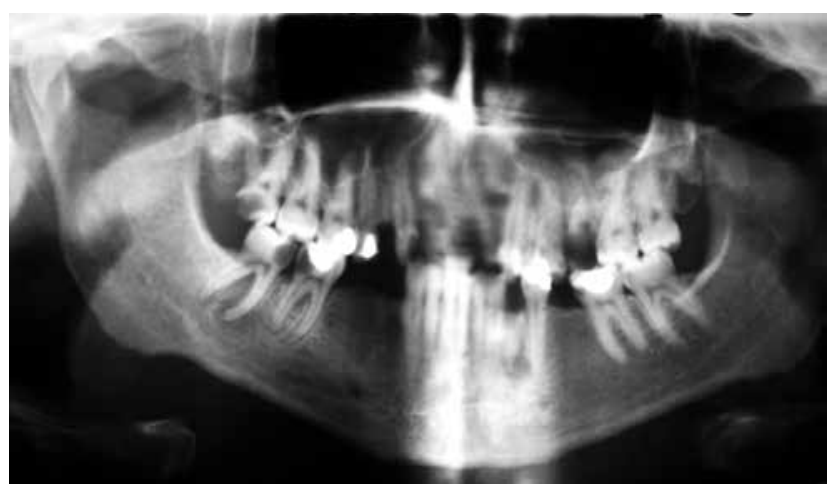

Fig. 1. Panoramic radiograph image - day of admission she underwent the removal of teeth deemed to constitute the foci of inflammation $(14,26,34,46,47)$; the abscess forming in the mental and submandibular regions was incised and drained. A small amount of sanguinopurulent material was obtained and passed on for bacteriological examination. Culture tests revealed the presence of Veillonella spp., sensitive to the following antibiotics: penicillin $\mathrm{G}$, amoxicillin, piperacillin, amoxicillin/clavulanic acid, metronidazole, clindamycin, and cefotetan. Blood and urine cultures were negative. On the next day, new purulent foci were incised and drained in the superolateral part of the neck; a small amount of fetid, brown, bloody material was obtained. Interfascial spaces were connected and, subsequently, rinsed multiple times with solutions of metronidazole and sodium bicarbonate. After the incision and evacuation of the abscess, the patient reported a slight improvement in her well-being and an improvement in her ability to swallow. Laboratory investigation revealed a drop in leukocytosis to $15800 / \mathrm{mm}^{3}$; the high level of CRP persisted $(53.7 \mathrm{mg} / \mathrm{dl})$, as did the electrolyte impairments - reduced potassium $\left(\mathrm{K}^{+} 2.6 \mathrm{mmol} / \mathrm{l}\right)$ and high glycemic values (up to $220 \mathrm{mg} / \mathrm{dl}$ ). Potassium supplementation was maintained, and, additionally, a second antibiotic was introduced (amoxicillin with clavulanic acid).

During the $5^{\text {th }}$ day of hospitalization, a stinging pain appeared in the patient's interscapular area, intensifying during deep inhalation and cough. In the respiratory tract, a dense, mucous secretion was present, which the patient was unable to expectorate, mostly due to strong pain. The dimensions of the cheek infiltrate decreased; a doughlike swelling of the neck persisted, but did not show a tendency for abscess formation. Large amounts of sanguinopurulent material were flowing out of the drained spaces. The patient did not present with fever. Plain chest $X$-ray revealed the presence of fluid in the left pleural cavity reaching rib VII in the posterior axillary line, an obscured contour of the right dome of the diaphragm and the right costophrenic angle, small atelectatic consolidations in the right lower lung field, and an increased cardiac silhouette (Fig. 2).

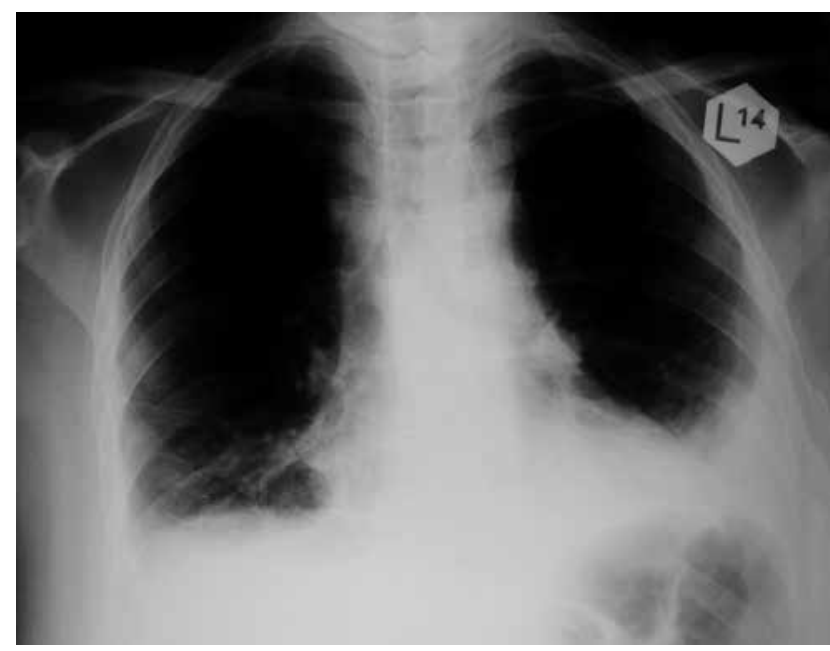

Fig. 2. Photograph of the patient's chest $-4^{\text {th }}$ day of hospitalization at the Department of Maxillofacial Surgery 
Left thoracocentesis was performed, but no fluid was obtained.

From the $6^{\text {th }} / 7^{\text {th }}$ day of hospitalization, the patient's condition began to deteriorate. The patient presented with fever, and leukocytosis increased to $21500 / \mathrm{mm}^{3}$. An internist consultation confirmed the suspicion of pneumonia and pleuritis as a complication of an odontogenic infection; additionally, steroid diabetes was revealed. Steroids were discontinued, and glycemic normalization was achieved.

The subsequently performed chest X-ray demonstrated an increased amount of fluid in both pleural cavities. Moreover, in the lower field of the right lung, a well-delineated shadow area $(5 \times 2.5 \mathrm{~cm}$ in size $)$ appeared, indicating the development of inflammation in this lobe. The patient continued to undergo bilateral pneumonia and pleuritis treatment. Bilateral thoracocentesis was performed; in total, over $200 \mathrm{ml}$ of fluid was evacuated and passed on for bacteriological examination.

As no significant improvement of the patient's general condition was achieved, a chest and neck CT was performed, revealing spaces with dense fluid (probably pus) in the left side of the neck and air-filled spaces reaching the level of the mandibular ramus. The fluid-filled spaces were located in the masseter muscle area, down to the parapharyngeal and retropharyngeal spaces, reaching laterally to the supraclavicular area and "entering" the chest - mediastinum. Lymph nodes of the neck increased in size to approximately $24 \mathrm{~mm}$. The mediastinum was enlarged, reaching the size of $95 \times 75 \mathrm{~mm}$, up to the level of the cardiac waistline. Singular abscesses were present in lung parenchyma; their largest sizes were $80 \mathrm{~mm}$ in the right lung and approximately $45 \mathrm{~mm}$ in the left. Furthermore, inflammatory congestions were found in both lungs. Fluid was present in the pleural cavities: up to $20 \mathrm{~mm}$ in width in the right cavity and up to $20 \mathrm{~mm}$ in the left. Subcarinal and paratracheal lymph nodes had increased in size to approximately $23 \mathrm{~mm}$. There were no focal lesions in the bone structure of the examined

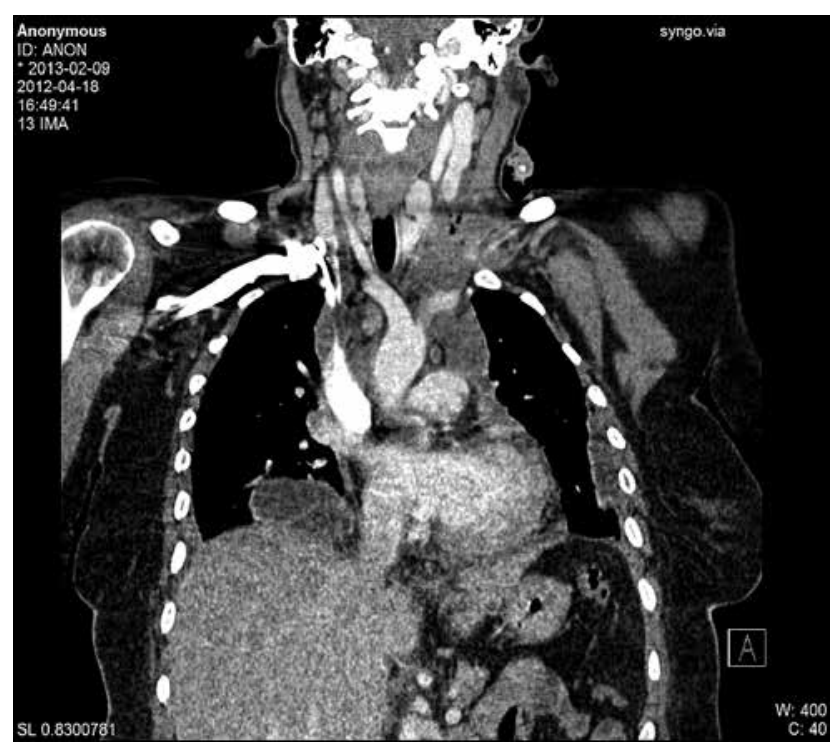

Fig. 3. Chest CT $-8^{\text {th }}$ day of hospitalization (preoperative image) area (Fig. 3). After a thoracic surgeon was consulted, the patient was qualified for urgent surgery due to mediastinal phlegmon and the suspicion of empyemas in both pleurae. Bilateral drainage of the parapharyngeal spaces and the mediastinum was performed via cervical access; right-sided thoracotomy with mediastinal incision and right lung decortication were conducted and followed with left-sided videoassisted thoracoscopic surgery (VATS). Opening the chest revealed the presence of organizing purulent material in the pleural cavity as well as necrotic lesions in the tissues of the mediastinum, extending to the pericardial sac and secreting purulent material. The mediastinum was widely incised and drained. Fibrin was removed from the pleura, and lung expansion was achieved. Irrigation drainage was introduced to the mediastinum and pleura. During the left-sided VATS, cloudy fluid was evacuated, adhesions were freed, fibrin was partially removed from the supradiaphragmatic area, and irrigation drainage was applied.

After the surgery, the patient, exhibiting symptoms of sepsis and postoperative respiratory failure, was transferred directly from the operating theater at the Department of Maxillofacial Surgery to the Department of Anesthesiology and Intensive Care (DAIC). At the DAIC, in severe condition and under analgosedation (midazolam, morphine sulfate), the patient was connected to a respirator in SIMV + PC mode. A central vein catheter and a radial artery cannula were introduced. The patient's life parameters were monitored continuously. Chest X-ray performed during the $1^{\text {st }}$ day of the patient's stay at the DAIC showed a regression of lesions. Samples of material from the bronchial tree (bronchofiberoscopy - BAL) were collected for bacteriological testing, along with pus drained from the pleural cavity and mediastinum, as well as blood and urine. Broad-spectrum antibiotic therapy was introduced (cefotaxime, amicacin, metronidazole), along with steroid therapy, anti-fungal therapy, anticoagulative treatment, fluid therapy, and parenteral feeding. During the $1^{\text {st }}$ day after thoracotomy, the patient's circulation was stable: SAP $110-120$ mmHg, HR 100-115/min, SatO 2 98-99\% with $\mathrm{FiO}_{2}$ at $40 \%$, diuresis $1500 \mathrm{ml} /$ day, normal body temperature. Tests for the presence of HBVag, anti-HCV, and HIV were negative. Klebsiella pneumoniae $\mathrm{ESBL}$ - a microorganism sensitive to the antibiotics already administered to the patient, was isolated from culture material collected from the bronchi. Wide access to the interfascial spaces of the neck was maintained; they were rinsed regularly in order to prevent premature occlusion of the draining duct. In accordance with the postoperative recommendations of the thoracic surgeon, irrigation drainage of both pleural cavities and the mediastinum was performed twice per day. Until the $6^{\text {th }}$ day, the patient's condition did not change: it was severe, but stable. The patient did not present with fever. Inflammation markers were reduced. Due to the long-lasting secretion of purulent material from the drains, another chest and neck CT was performed. The CT image showed no expected signs of lesion regression. Moreover, a new fluid-filled lesion appeared in the 
right pleural cavity, along with changes suggesting pneumonia (Fig. 4).

Another drain was introduced under ultrasound control. During the procedure, the partially adhesed surface of the lower lobe of the right lung was injured. Bleeding was stopped pharmacologically, and the air leak, despite mechanical ventilation, was small and subsided on its own. During the $8^{\text {th }}$ day at the DAIC, the patient's condition deteriorated. Her body temperature rose rapidly to $39.2^{\circ} \mathrm{C}$, and ventilation conditions worsened, requiring the increase of $\mathrm{FiO}_{2}$ to 0.5 . Acid-base balance examination revealed hypoxic respiratory acidosis. More cultures were obtained for bacteriological testing. Due to progressing anemia, the patient was transfused with 4 units of packed red blood cells (Fig. 5). During the $10^{\text {th }}$ day at the DAIC, the patient's general conditioned continued to deteriorate significantly. With $\mathrm{FiO}_{2}$ at $50-100 \%$, SatO 2 would drop to $50 \%$. At times, chest rigidity would set in, rendering normal ventilation impossible. A non-depolarizing blocking agent (vecuronium) was added to the therapy, achieving a slight improvement in terms of ventilation conditions. Laboratory tests revealed a rise in "septic" parameters, and the fever persisted (up to $39.3^{\circ} \mathrm{C}$ ). The results of cultures from the right pleural cavity indicated the presence of Acinetobacter baumannii, a multiresistant bacterial strain resistant to the antibiotics previously administered to the patient. In accordance with the antibiogram, meropenem was added to the treatment. The result of blood cultures was also positive. A multiresistant strain of Enterococcus faecium, sensitive to linezolid, was cultured; linezolid was subsequently added to the therapy. During the $11^{\text {th }}$ day, the patient's arterial pressure dropped despite fluid therapy. Pressor amines (norepinephrine) were added to the therapy. Despite intensive treatment, signs of multiple organ dysfunction syndrome intensified. The therapy was unsuccessful: the patient died during the $12^{\text {th }}$ day of treatment at the DAIC.

\section{Discussion}

Abscesses and odontogenic inflammatory conditions of the head and neck are often encountered in clinical practice and are usually not difficult to diagnose and treat. In rare cases, such infections may spread through the interfascial spaces of the neck to the chest and mediastinum $[1,2]$. The DNM case of a 26-year-old woman described above is an example of a complication which posed a significant diagnostic and treatment challenge and resulted in the patient's death. Most authors list odontogenic infections related to pulp infections of the lower molars as the primary cause of DNM $[3,4]$. According to statistical data, such infections are responsible for $50-80 \%$ of DNM occurrences. In the present case, the purulent complications also originated from dental neglect and the fact that the pulp of numerous lower molars of the patient was in a state of gangrenous decay. The literature underscores that the typical bacterial flora of the upper airway and the gastrointestinal tract plays an important role in the etiopathogenesis of DNM $[5,6]$. This

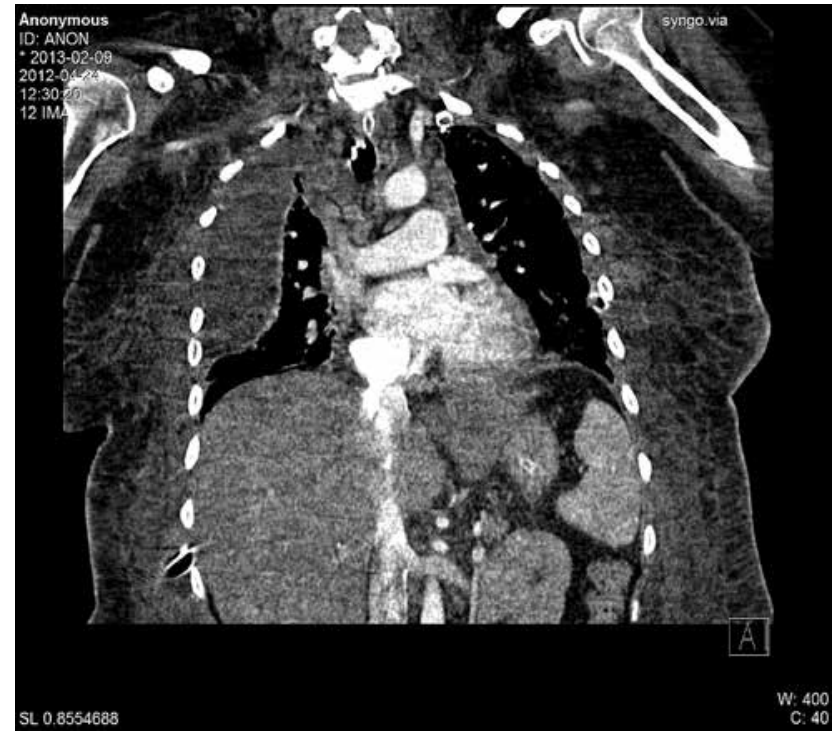

Fig. 4. Chest $\mathrm{CT}-14^{\text {th }}$ day of hospitalization $/ 5^{\text {th }}$ postoperative day

has also been confirmed by our own observations. In the present case, a mixed bacterial flora was revealed by culture tests: Veillonella ssp., Streptococcus anginosus, Candida albicans, Klebsiella pneumoniae, Enterococcus faecium, and Acinetobacter baumannii. Descending necrotizing mediastinitis is a rare complication; according to Freeman, even thoracic surgeons rarely encounter this disease during their professional careers. It is, therefore, understandable that this complication constitutes a significant problem in the practice of various specialized fields, including maxillofacial surgery. Knowledge of the pathogenesis and symptoms of DNM is of cardinal significance in diagnosing, treating, and predicting the course of the disease. The clinical symptoms of DNM observed in our patient were similar to those

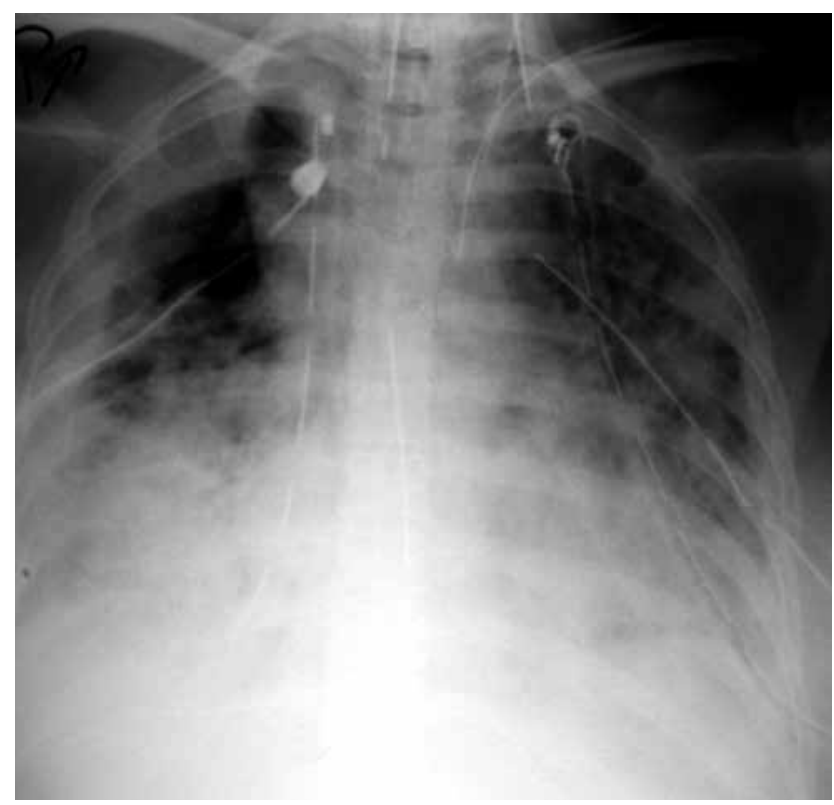

Fig. 5. Photograph of the patient's chest $-17^{\text {th }}$ day of hospitalization (ARDS image) 
described in the literature [7-9]; however, it appears that they were erroneously interpreted as the signs of concomitant respiratory tract infection, which delayed the correct diagnosis. Deterioration of the patient's general condition, growing leukocytosis, and rising CRP and PCT values are indications for supplementing the diagnostic investigation with head, neck, and chest CT with contrast. Literature data demonstrate the superiority of CT over conventional chest $X$-ray examinations in the early diagnosis of DNM. The present case confirms the above, as the initial changes visible on the X-ray image were non-specific, and DNM was only diagnosed after the performance of a CT scan. In terms of surgical treatment, it is of fundamental importance to remove any necrotic tissue as well as bacteria and their toxins and, subsequently, employ irrigation drainage.

In conclusion, it should be underscored that chest pain, cough, and lack of improvement in the general condition of a patient after the drainage of abscesses around the jaw and neck should be indicative of remote lung complications, including DNM. Our observations confirm that, in the treatment of complicated inflammatory conditions of the head and neck, multi-specialist cooperation of maxillofacial surgeons, thoracic surgeons, and intensive care specialists, as well as, in some cases, otolaryngologists, is indispensable.

\section{References}

1. Rokicki M, Rokicki W, Rokicki Jr M. Zstępujące martwicze zapalenie śródpiersia - postępowanie diagnostyczne i leczenie chirurgiczne. Kardiochir Torakochir Pol 2006; 3: 389-393.

2. Rocca F, Pecorari GC, Oliaro A, Passet E, Rossi P, Nadalin J, Garzino-Demo P, Berrone $S$. Ten years of descending necrotizing mediastinitis: management of 23 cases. J Oral Maxillofac Surg 2007; 65: 1716-1724.

3. Mihos P, Potaris K, Gakidis I, Papadakis D, Rallis G. Management of descending necrotizing mediastinitis. J Oral Maxillofac Surg 2004; 62: 966-972.

4. Sakamoto H, Aoki T, Kise Y, Watanabe D, Sasaki J. Descending necrotizing mediastinitis due to odontogenic infections. Oral Surg Oral Med Oral Pathl Oral Radiol Endod 2000; 89: 412-419.

5. Sandner A, Borgermann J, Kosling S, Silber RE, Bloching MB. Descending necrotizing mediastinitis: early detection and radical surgery are crucial. J Oral Maxillofac Surg 2007; 65: 794-800.

6. Rokicki M, Rokicki W, Gawrychowski J, Filipowski M. Czy stały, płuczący drenaż śródpiersia jest bezpiecznym i skutecznym sposobem leczenia zstępującego martwiczego zapalenia śródpiersia. Kardiochir Torakochir Pol 2006; 3: 169-173.

7. Wanyura H, Chabowski M, Kuca R, Kamiński A, Orłowski TM, Kowalska K. Zstępujące martwicze zapalenie śródpiersia - powikłanie procesu zapalnego w obrębie tkanek twarzy i szyi. Czas Stomatol 2005; 58: 658-666.

8. Rokicki M, Rokicki W, Rokicki Jr M, Lewandowski R, Zygo A. Zstępujące, martwicze zapalenie śródpiersia pochodzenia zębowego. Czas Stomatol 2007; 60: 456-465.

9. Wojtuń K, Kądziołka W, Kobak G, Kądziołka J. Ropień śródpiersia przedniego jako ciężkie powikłanie urazu komunikacyjnego. Kardiochir Torakochir Pol 2010; 7: 436-438.

\section{Disclosure}

The authors report no conflict of interest. 